\title{
Uptake and metabolism of androgen by the human epididymis in vitro
}

\author{
María A. de Larminat, M. J. Hinrichsen, C. Scorticati*, J. M. Ghirlanda $\dagger$, \\ J. A. Blaquier and R. S. Calandra
}

Instituto de Biología y Medicina Experimental, Obligado 2490, Buenos Aires 1428; * Servicio de Urología, Instituto de Oncología Angel H. Roffo, Universidad de Buenos Aires; and

† Cátedra de Urología, Hospital de Clínicas Gral. José de San Martín, Universidad de Buenos Aires, Buenos Aires, Argentina

\begin{abstract}
Summary. Uptake and metabolism of $\left[{ }^{3} \mathrm{H}\right]$ testosterone, mainly to $5 \alpha$-dihydro-

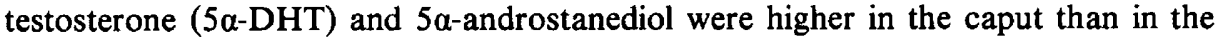
cauda epididymidis in vitro. The metabolites represented 57,49 and $47 \%$ of the total radioactivity in the caput, corpus and cauda epididymidis, respectively; subcellular distributions of the metabolites in each segment showed $67 \%$ of total radioactivity in cytosol and $18 \%$ in the nuclei. In both fractions, the amount of $5 \alpha$-DHT was greater than that of androstanediol while the reverse was true for the mitochondria and microsomes.

The distribution of $5 \alpha$-reductase activity in subcellular fractions was similar to that of the microsomal marker enzyme NADPH: cytochrome $\mathrm{C}$ reductase, whilst $3 \alpha$-hydroxysteroid dehydrogenase was found mainly in the cytosol. Maximal $5 \alpha$-reductase activity was at $\mathrm{pH} 5 \cdot 3$, apparent $K_{\mathrm{m}}$ values in the microsomal and nuclear fractions were $1.65 \pm 0.7$ and $1.75 \pm 0.36 \times 10^{-6} \mathrm{M}$ respectively, and the $V_{\max }$ in these preparations was $5.28 \pm 1.19$ and $3.1 \pm 0.52 \mathrm{pmol} / \mathrm{mg}$ protein $/ \mathrm{min}$, respectively. The activity of $5 \alpha$-reductase was inhibited by $\mathrm{Zn}^{2+}, \mathrm{Cu}^{2+}, \mathrm{Ba}^{2+}$ and $\mathrm{Cd}^{2+}$ and by epitestosterone, progesterone and 4-androstene-3-one-17 $\beta$-carboxylic acid.
\end{abstract}

\section{Introduction}

Evidence gathered from several different laboratory species has shown that the maintenance of normal morphology and function of the epididymis are androgen dependent (Hamilton, 1975) and that circulating testosterone is necessary for spermatozoa to acquire and retain their fertilizing capacity (Orgebin-Crist, Danzo \& Davies, 1975). These androgen-dependent events are initiated following the uptake of testosterone by the epididymis, its conversion to the more active hormone $5 \alpha$-dihydrotestosterone $(5 \alpha$-DHT) and its binding to specific receptors (Gloyna \& Wilson, 1969; Blaquier, 1971; Hansson, Ritzén, French \& Nayfeh, 1975).

This general scheme of androgen action has been found for the rhesus monkey epididymis (Blaquier, 1974; de Larminat \& Blaquier, 1978), but there is little information regarding the epididymis in man. In the present study we have investigated the uptake and metabolism of androgens by the human epididymis in vitro and partly characterized the enzyme NADPH: $\Delta^{4}$ $5 \alpha$-reductase (EC 1.3.1.22) (5a-reductase) which catalyses the transformation of testosterone into $5 \alpha$-DHT. 


\section{Materials and Methods}

The following radioactive steroids were purchased from New England Nuclear (Boston, Massachusetts, U.S.A.): $\left[1,2-{ }^{3} \mathrm{H}\right]$ testosterone (sp. act. $41 \mathrm{Ci} / \mathrm{mmol}$; $\left[1,2-{ }^{3} \mathrm{H}\right]$ dihydrotestosterone (sp. act. $50.6 \mathrm{Ci} / \mathrm{mmol}$ ) and $\left[4-{ }^{14} \mathrm{C}\right]$ dihydrotestosterone (sp. act. $57 \mathrm{mCi} / \mathrm{mmol}$ ). $\left[4-{ }^{14} \mathrm{C}\right] 5 \alpha$-Androstan-3 $\alpha, 17 \beta$-diol was prepared as described previously (Monsalve \& Blaquier, 1977). Non-radioactive steroids were obtained from Steraloids Inc. (Wilton, New Hampshire, U.S.A.) and all other chemicals and reagents were of analytical grade.

Human epididymides were obtained from 8 patients undergoing orchidectomy as treatment for metastatic prostate carcinoma. The patients selected for this study had not received any hormonal or radiation therapy during the 6 months preceding the operation. The average age was 65.9 years (range 55-76 years). After removal, the testes and epididymides were immediately placed on ice and transported to the laboratory where all subsequent procedures were performed at $4^{\circ} \mathrm{C}$. After removal of the tunica albuginea, the testis and the adherent fat were separated from each epididymis, which was then divided into three segments corresponding to the caput, corpus and cauda epididymidis (corresponding to segments $1 \mathrm{~b}-2 \mathrm{~b} ; 3-3 \mathrm{~b}$ and $3 c-4 c$, respectively, illustrated in Text-fig. 1 by Bedford, Calvin \& Cooper, 1973).

Androgen uptake and metabolism studies. The tissues were minced with scissors and aliquots (300 mg) were incubated for $1 \mathrm{~h}$ at $33^{\circ} \mathrm{C}$ in $2 \mathrm{ml} \mathrm{Krebs-Ringer-phosphate} \mathrm{(Umbreit,} \mathrm{Burris} \mathrm{\&}$ Stauffert, 1957) glucose buffer, $\mathrm{pH} 7.4$, containing $1.8 \times 10^{6}$ d.p.m. $\left[{ }^{3} \mathrm{H}\right]$ testosterone $\left(10^{-8} \mathrm{M}\right)$. The preparation was extensively washed with buffer and homogenized in 4 volumes of 20 mM-Tris, pH 7.4 containing $3 \mathrm{mM}^{-\mathrm{CaCl}_{2}}$ and $0.15 \mathrm{M}$-sucrose. Subcellular fractions were prepared by differential centrifugation as described previously (Monsalve \& Blaquier, 1977).

After addition to tracer amounts of $\left[{ }^{14} \mathrm{C}\right] 5 \alpha$-DHT and $\left[{ }^{14} \mathrm{C}\right]$ androstanediol, the fractions were extracted with 2 volumes of ethyl acetate. The ethyl acetate was separated from the aqueous phase and evaporated. The sediment was dissolved in chloroform:methanol $(2: 1 \mathrm{v} / \mathrm{v})$ and aliquots of this mixture were chromatographed on silica gel plates (Eastman Kodak, New York, U.S.A.) with chloroform:either $(4: 1 \mathrm{v} / \mathrm{v})$ as the eluant and carrier androstenedione and testosterone. The plates were visualized under u.v. light and the radioactive steroids were located. The corresponding zones were scraped into columns and eluted with methanol. After evaporation, the sediment was dissolved in a toluene-based scintillation fluid and the radioactivity was counted.

Assay for $5 \alpha$-reductase. Aliquots of the subcellular fractions were incubated for different periods of time at $33^{\circ} \mathrm{C}$ in the presence of $1 \mathrm{~mm}-\mathrm{NADPH}$ and $\left[{ }^{3} \mathrm{H}\right]$ testosterone at concentrations ranging from $10^{-7}$ to $5 \times 10^{-6} \mathrm{M}$ and $5 \alpha$-reductase (EC 1.3.1.22) activity was measured as described by Monsalve \& Blaquier (1977). The activity of $3 \alpha$-hydroxysteroid dehydrogenase (EC 1.1.1.50) was determined in the same way but with $\left[{ }^{3} \mathrm{H}\right] 5 \alpha$-dihydrotestosterone as the substrate.

Table 1. Uptake and metabolism of $\left[{ }^{3} \mathrm{H}\right]$ testosterone by different segments of the human epididymis

\begin{tabular}{lccc}
\hline & \multicolumn{3}{c}{ Epididymis } \\
\cline { 2 - 4 } & Caput & Corpus & Cauda \\
\hline Uptake (d.p.m. $\left.\times 10^{6}\right)$ & $2.40 \pm 0.11$ & $1.86 \pm 0.08$ & $1.74 \pm 0.08$ \\
Metabolism (\%) & & & \\
$\quad$ Testosterone & $43.48 \pm 2.00$ & $50.94 \pm 6.72$ & $53.06 \pm 4.33$ \\
5a-DHT & $40.58 \pm 1.87$ & $28.31 \pm 3.37$ & $28.57 \pm 2.33$ \\
Androstanediol & $16.08 \pm 0.74$ & $20.75 \pm 2.74$ & $18.37 \pm 1.50$ \\
\hline
\end{tabular}

Values are mean \pm s.e.m. for 3 experiments, performed with tissues from 3 different patients. Results were normalized for $1 \mathrm{~g}$ tissue wet weight and metabolism data are expressed as \% of the total radioactivity in each segment. 
After incubation, testosterone, $5 \alpha$-dihydrotestosterone and androstanediol were extracted and separated as described above; $5 \alpha$-reductase activity was expressed as the sum total of $5 \alpha$-DHT and androstanediol formed at $33^{\circ} \mathrm{C}$ per mg protein and per unit of time.

For the determination of $K_{\mathrm{m}}$ and $V_{\max }$ values the subcellular fractions were incubated in triplicate for $20 \mathrm{~min}$ at $33^{\circ} \mathrm{C}$ with $0 \cdot 1,0 \cdot 2,0 \cdot 5,1,2$ and $5 \mu \mathrm{M}-\left[{ }^{3} \mathrm{H}\right]$ testosterone and the results were represented as Lineweaver-Burke plots. Protein concentrations were determined by the method of Lowry, Rosebrough, Farr \& Randall (1951). The activity of NADPH cytochrome C reductase (EC 1.6.2.4) was estimated as described by Avruch \& Hoelzl (1971).

\section{Results}

\section{Uptake and metabolism}

After incubation of the minced epididymides with $\left[{ }^{3} \mathrm{H}\right]$ testosterone, $33 \%$ of the radioactivity was retained within the tissue. The uptake of $\left[{ }^{3} \mathrm{H}\right]$ testosterone was highest in the caput epididymidis and lower in the other segments (Table 1). A large proportion of the testosterone was, however, converted to metabolites which had the chromatographic mobility of $5 \alpha$-DHT and $5 \alpha$-androstanediol (Monsalve \& Blaquier, 1977). These represented 57, 49 and $47 \%$ of the radioactivity in the caput, corpus and cauda segments respectively. In all cases $5 \alpha$-DHT was more abundant than androstanediol. The androstanediol fraction consisted of a mixture of the $3 \alpha-$ and $3 \beta$-isomers which were not separated by the chromatography system used in this study. There was proportionally more $5 \alpha$-DHT in the caput epididymidis $(41 \%)$ than in the corpus and cauda ( 28 and $29 \%$ respectively).

The subcellular distribution of the incorporated steroids was uniform throughout the organ. Most of the radioactivity was associated with the cytosol $(67 \%)$ and nuclei $(18 \%)$, the mitochondria and microsomes containing 8.1 and $6.3 \%$ of the radioactivity, respectively.

The extent to which $\left[{ }^{3} \mathrm{H}\right]$ testosterone was metabolized differed in the 3 segments (Text-fig. 1). Caput cytosol and nuclei contained more $5 \alpha$-reduced steroids ( 73 and $66 \%$, respectively)

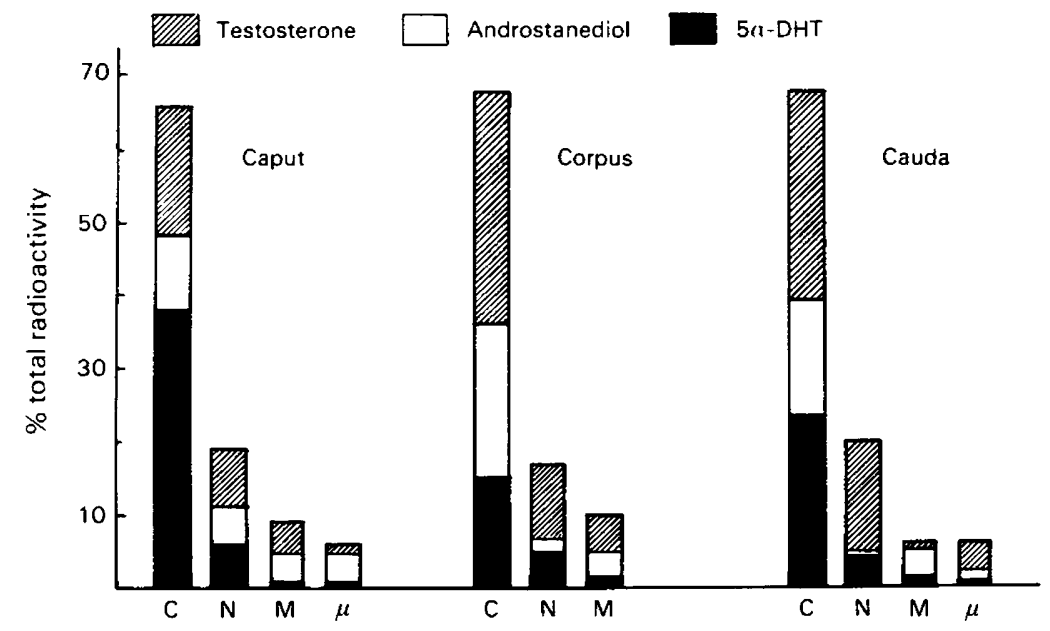

Text-fig. 1. Results for 3 epididymides showing the subcellular localization of $\left[{ }^{3} \mathrm{H}\right]$ testosterone and its metabolites ( $5 \alpha$-androstanediol and $5 \alpha$-dihydrotestosterone) in the caput, corpus and cauda segments. Aliquots $\left(300 \mathrm{mg}\right.$ ) of the tissues were incubated with $10^{-8} \mathrm{M}\left[{ }^{3} \mathrm{H}\right]$ testosterone for $1 \mathrm{~h}$ at $33^{\circ} \mathrm{C}$. The results were normalized to $1 \mathrm{~g}$ tissue wet weight and expressed as the percentage of total radioactivity found in each fraction. The subcellular fractions were cytosol $(\mathrm{C})$, nuclei $(\mathrm{N})$, mitochondria $(\mathrm{M})$ and microsomes $(\mu)$. The microsome fractions from the corpus segment were accidentally lost. 
than did the corresponding fractions from the corpus ( 50 and $39 \%$ ) or cauda ( 59 and $24 \%$ ). The proportion of $5 \alpha$-DHT in the $5 \alpha$-reduced fraction was also variable throughout the epididymis, representing 76 and $50 \%$ for caput cytosol and nuclei, 44 and $69 \%$ in the corpus and 55 and $82 \%$ for these fractions in the cauda epididymidis. While 5 $\alpha$-DHT was, in general, the predominant $5 \alpha$-reduced metabolite in the nuclei and cytosol, androstanediol was always more abundant in the mitochondrial and microsomal fractions.

\section{Characteristics of $5 \alpha$-reductase}

As shown by Text-figs 2(a) and 2(b) the distribution of $5 \alpha$-reductase activity was very similar to that of NADPH :cytochrome C reductase. Since the latter is a microsomal marker enzyme, $5 \alpha$-reductase is probably also associated with the microsomal membranes. The activity of 3-hydroxysteroid dehydrogrenase was located mainly in the soluble fraction (Text-fig. 2c). The activity of the microsomal $5 \alpha$-reductase was maximal at $\mathrm{pH} 5 \cdot 3$ (Text-fig. 3 ).

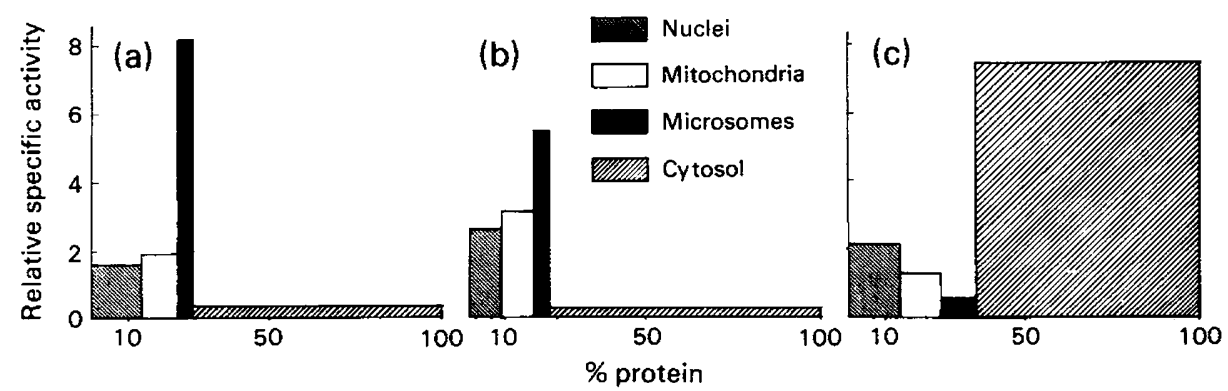

Text-fig. 2. Subcellular distribution of (a) $5 \alpha$-reductase, (b) NADPH : cytochrome C reductase and (c) 3-hydroxysteroid dehydrogenase activities in the human epididymis. Results $(n=2)$ are mean values of data from 4 experiments and are expressed as the relative specific activity (\% total activity $/ \%$ total protein content) plotted against the cumulative value for the $\%$ protein content.

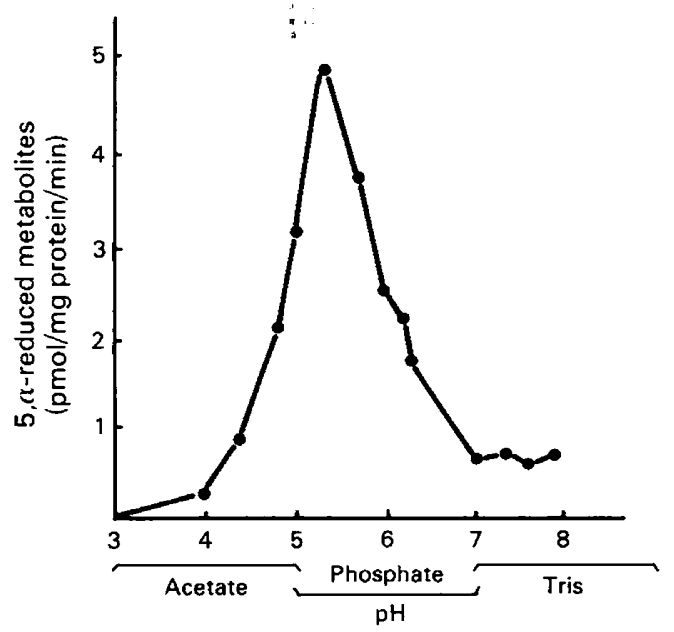

Text-fig. 3. Effect of $\mathrm{pH}$ on the 5a-reductase activity of the microsomal fraction from the human epididymis. Aliquots of the microsomal fraction were incubated with $1 \mu \mathrm{M}-\left[{ }^{3} \mathrm{H}\right]$ testosterone and $1 \mathrm{~mm}$-NADPH for $30 \mathrm{~min}$ at $33^{\circ} \mathrm{C}$. Buffers were calibrated at intervals of 0.25 units of $\mathrm{pH} ; 20$

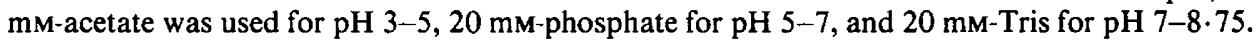


When different bivalent cations were tested, at a concentration of $1 \mathrm{~mm}$ in the medium, $\mathrm{Zn}^{2+}$ had the greatest inhibitory effect $\left(46 \pm 3 \cdot 22 \%\right.$ inhibition), with $\mathrm{Cu}^{2+}(32 \pm 2 \cdot 24 \%), \mathrm{Ba}^{2+}(25 \pm$ $1.75 \%)$ and $\mathrm{Cd}^{2+}(21 \pm 1.47 \%)$ being less effective. $\mathrm{Ca}^{2+}(105 \pm 7.35 \%)$ had no effect. Addition of $17 \alpha$-hydroxy-4-androsten-3-one, progesterone and 4-androsten-3-one,17 $\beta$-carboxylic acid, at concentrations of $1 \mu \mathrm{M}$, resulted in $66 \pm 4.62,64 \pm 4.48$ and $55 \pm 3.85 \%$ inhibition respectively. The addition of $5 \alpha$-DHT or androstanediol $\left(10^{-6} \mathrm{M}\right)$ to the incubation medium did not modify $5 \alpha$-reductase activity.

The values (mean \pm s.e.m. for 3 observations) obtained for $V_{\max }$ and the apparent $K_{\mathrm{m}}$ were $3.1 \pm 0.52 \mathrm{pmol} / \mathrm{mg}$ protein $/ \mathrm{min}$ and $1.75 \pm 0.36 \times 10^{-6} \mathrm{M}$ respectively for the nuclear preparation, and $5.28 \pm 1.19 \mathrm{pmol} / \mathrm{mg}$ protein $/ \mathrm{min}$ and $1.65 \pm 0.70 \times 10^{-6} \mathrm{M}$ respectively for the microsomal preparation.

\section{Discussion}

The results of this study show that the human epididymis is capable of the uptake and retention of androgens. The comparison of the segmental distribution of radioactivity suggests that androgens are concentrated in the caput region, while the analysis of the subcellular distribution indicates that these steroids are found mostly in the cytosol and nuclei.

Testosterone is extensively converted to its $5 \alpha$-reduced metabolites, as shown by Gloyna \& Wilson (1969) and Sulcová \& Starka (1973) and the caput segment was more active in this regard than the corpus and cauda. The ratio of $5 \alpha$-DHT:androstanediol varied in each segment, being highest in the caput. This was also the case when this ratio was determined in subcellular fractions from each segment. Caput cytosol and nuclei contained a higher proportion of $5 \alpha$-DHT than did the same fractions from other segments. The extent of the reduction of testosterone suggests that this is a physiologically important mechanism for androgen action in the human epididymis. Purvis, Calandra, Sander \& Hansson (1978) measured the endogenous androgen concentration in human testis and epididymis and found that the testosterone: $5 \alpha$ DHT ratio was highly variable: 106 in the testis and only 3.6 in the epididymis. The change was due not only to a decrease in the testosterone content in the epididymis, but also to the fact that this organ contained almost twice as much $5 \alpha$-DHT as did the testis, thus suggesting the local production of this steroid. Purvis et al. (1978) also determined the testosterone : $5 \alpha$-DHT ratio in a semipurified epididymal fraction, enriched in cytoplasmic receptor; the value obtained was 0.6 , showing a relative 6 -fold increase in the concentration of 5 $\alpha$-DHT. Taken together, these results strongly suggest that the epididymis in man utilizes androgens in a manner similar to that shown for rats in which $5 \alpha$-DHT interacts with epididymal intracellular receptors and thus mediates the effects of testosterone for the maintenance of epididymal function (Orgebin-Crist et al., 1975).

Our present results, showing that most of the $5 \alpha$-reductase activity is associated with membranes of the endoplasmic reticulum in the human epididymis, agree with previous reports on the subcellular localization of this enzyme in the rat (Monsalve \& Blaquier, 1977) and monkey (de Larminat \& Blaquier, 1978) epididymis, as well as in other androgen target tissues (Chamberlain, Jagarineck \& Ofner, 1966; Voigt, Fernández \& Hsia, 1970; Moore \& Wilson, (1972).

Further similarity between the $5 \alpha$-reductase in the human epididymis and that in the rat (Monsalve \& Blaquier, 1977) and monkey (de Larminat \& Blaquier, 1978) is shown by the acidic $\mathrm{pH}$ value for optimum activity, the correspondence of $K_{\mathrm{m}}$ values and the decreases in enzyme activity caused by the presence of bivalent cations or steroids.

This work was partly supported by grant 780-0349 from the Ford Foundation and World Health Organization (project 73014). J.A.B. and R.S.C. are members of the Research Career, National Research Council, Argentina. We thank Mrs Patricia Delcourt for skilful technical assistance. 


\section{References}

Avruch, J. \& Hoelzl, D. (1971) Preparation and properties of plasma membrane and endoplasmic reticulum fragments from isolated fat cells. Biochim. Biophys. Acta 233, 334-347.

Bedford, J.M., Calvin, H. \& Cooper, G.W. (1973) The maturation of spermatozoa in the human epididymis. J. Reprod. Fert., Suppl. 18, 199-213.

Blaquier, J.A. (1971) Selective uptake and metabolism of androgens by rat epididymis. The presence of a cytoplasmic receptor. Biochem. Biophys. Res. Commun. 45, 1076-1087.

Blaquier, J.A. (1974) Androgen receptors from the epididymis of the Rhesus monkey. Endocr. Res. Commun. 1, 155-167.

Chamberlain, J., Jagarineck, N. \& Ofner, P. (1966) Catabolism of $\left[4-{ }^{14} \mathrm{C}\right]$ testosterone by subcellular fractions of human prostate. Biochem. J. 99, 610616.

de Larminat, M.A. \& Blaquier, J.A. (1978) Androgen concentration and partial characterization of $5 \alpha$ reductase in the epididymis of the Rhesus monkey. Steroids 31, 129-138

Gloyna, R. E. \& Wilson, J.D. (1969) A comparative study of the conversion of testosterone to $17 \beta$ hydroxy-5 $\alpha$-androstan-3-one(dihydrotestosterone) by prostate and epididymis. J. clin. Endocr. Metab. 29, 970-977.

Hamilton, D.W. (1975) Structure and function of the epithelium lining the ductuli efferentes, ductus epididymides, and ductus deferens in the rat. In Handbook of Physiology, section 7, vol. V, pp. 259-301. Eds D.W. Hamilton \& R.O. Greep. Am. Physiol. Soc., Washington, D.C.

Hansson, V., Ritzén, E.M., French, F.S. \& Nayfeh, S.N. (1975) Androgen transport and receptor mechan- isms in testis and epididymis. In Handbook of Physiology, section 7, vol. V, pp. 173-201. Eds D.W. Hamilton \& R.O. Greep. Am. Physiol. Soc., Washington, D.C.

Lowry, O.H., Rosebrough, N.J., Farr, A.L. \& Randall, R.J. (1951) Protein measurement with the Folin phenol reagent. J. biol. Chem. 193, 265-275.

Monsalve, A. \& Blaquier, J.A. (1977) Partial characterization of epididymal $5 \alpha$-reductase in the rat. Steroids 30, 41-51.

Moore, R.J. \& Wilson, J.D. (1972) Localization of NADPH : $\Delta^{4}-3$ ketosteroid-5 $\alpha$-oxidoreductase in the nuclear membrane of the rat ventral prostate. J. biol. Chem. 247, 958-967.

Orgebin-Crist, M.C., Danzo, B.J. \& Davies, J. (1975) Endocrine control of the development and maintenance of sperm fertilizing ability in the epididymis. In Handbook of Physiology, section 7, vol. V, pp. 319-338. Eds D.W. Hamilton \& R.O. Greep. Am. Physiol. Soc., Washington, D.C.

Purvis, K., Calandra, R.S., Sander, S. \& Hansson, V. (1978) Androgen binding proteins and androgen levels in the human testis and epididymis. Int. J. Androl. 1, 531-562.

Sulcová, J. \& Starka, L. (1973) The metabolism of androgens in normal human testis and epididymis. Endocr. exp. 7, 113-118.

Umbreit, W.W., Burris, R.H. \& Stauffert, J.F. (1957) Manometric Techniques, p. 149. Burgess Publishing Co., Minneapolis.

Voigt, W., Fernández, E.P. \& Hsia, S.L. (1970) Transformation of testosterone into $17 \beta$-hydroxy-5a-androstan-3-one by microsomal preparations of human skin. J. biol. Chem. 245, 5594-5599.

Received 16 October 1979 